\title{
Yield and Economic Viability of Tomato (Solanum lycopersicum Mill) under Front Line Demonstrations in Kanker District, Chhattisgarh, India
}

\author{
Suresh Kumar Markam ${ }^{1 *}$, Birbal Sahu ${ }^{2}$, Komal Singh Keram ${ }^{3}$ and Chandu Lal Thakur ${ }^{2}$ \\ ${ }^{1}$ Department of Horticulture, ${ }^{2}$ Department of Agronomy, ${ }^{3}$ Department of Soil Sceince and \\ Agricultural Chemistry, Krishi Vigyan Kendra, Kanker, IGKV, Raipur (CG), India \\ *Corresponding author
}

\section{Keywords}

Front line

demonstration,

Tomato, B:C Ratio,

Extension gap and

Technology index

Article Info

Accepted:

12 November 2019

Available Online:

10 December 2019
A B S T R A C T

Tomato (Solanum lycopersicum Mill) is one of the important fruit vegetable crops grown for fresh and processing purpose all over the India due to its wider adaptability under various agro- climatic conditions, which plays a major role in supplementing the income of small and marginal farmer of the Kanker district of Chhattisgarh state. The present study was carried out at Kanker district during rabi 2016-17. Front line demonstrations were conducted on tomato by the active participation of the farmers with the objective of improved technologies of tomato production potential. The improved technologies consist triple disease resistant hybrid variety (Arka rakshak), balanced fertilizers (Soil test based) application and integrated pest and disease management, etc. The development of the Agriculture is primarily depends on the application of the scientific technologies by making the best use of available resources. One of the major constraints of traditional tomato farming is low productivity because of non-adoption of advanced technologies like improved varieties. To increase the production, productivity and quality of agricultural produce, front line demonstrations are being conducted at various farmers' field. All the recommended practices were provided to the selected farmers. The data related to the cost of cultivation, production, productivity, gross return and net return were collected as per schedule and analyzed. Result of the present study revealed that higher yield in the demonstrations was recorded $\left(471 \mathrm{q} \mathrm{ha}^{-1}\right)$ as compared to farmers practice $(376 \mathrm{q}$ $\mathrm{ha}^{-1}$ ) traditionally adopted by the farmers. The percentage increase in the yield over farmer's practice 25.26 was recorded. The technology gap, extension gap and technology index were computed $279 \mathrm{q} \mathrm{ha}^{-1}, 95 \mathrm{q} \mathrm{ha}^{-1}$ and $37.2 \%$ respectively. The demonstrated field gave higher net return Rs. 155950 and B:C ratio and incremental $\mathrm{B}: \mathrm{C}$ ratio is 1:3.27 and 1:3.11 respectively. The result of the study indicated the gap existed in the potential yield and demonstration yield is due to soil fertility and weather conditions. Present results clearly show that the yield and economics of tomato can be boost up by adopting recommended technologies. 


\section{Introduction}

To cater to the needs of farmers and for transfer of technology from lab to land, Krishi Vigyan Kendras (KVKs) have been established by various State Agriculture Universities SAUs as well as Government under Indian Council of Agricultural Research ICAR system in all the states. At present, there are $706 \mathrm{KVKs}$-about one KVK in each district -which interact with farmers and impart training and knowledge about the new technologies and practices. The KVKs have twin roles one is training of farmers in new technologies and another is dissemination. It was also envisaged that technology assessed by the KVKs will be act as model for the line departments and as a catalyst to improve the existing system for better delivery mechanism. The KVKs organize front line demonstrations (FLDs) which aims at demonstrating newly released and pre - released production technologies of cereals, pulses and vegetables on farmers fields. KVKs are playing strategic role in technology back stopping, knowledge management and advisory to the different stake holders like farmers, farm women, rural youths and extension personnel. (Anonymous, 2015).

Tomato (Lycopersicon esculentum Mill.) is an important vegetable crop grown almost throughout the world including tropical and temperate regions. It is cultivated both in the green houses on protective structures as well as under natural conditions. Tomato is a rich source of vitamins A and C and is referred to as "poor man's orange". It adds variety of colours to the food. Tomato is a very good appetizer and its soup is said to be a good remedy for patients suffering from constipation. Lycopene that imparts red colour to ripe tomatoes is reported to possess anticancerous properties. It also serve as a natural anti-oxidant as the Beta-carotene functions to help prevent and neutralize free radical chain reaction and ascorbic acid is an effective scavenger of superoxide, hydrogen peroxide, singlet oxygen and other free radicals (Dhaliwal, 2014). It can be grown in almost all states of India except in higher altitudes. Bihar, Karnataka, Uttar Pradesh, Orissa, Andhra Pradesh, Maharashtra, Madhya Pradesh, Punjab, Haryana and Assam are important tomato growing states in India.

In India during 2017-18 it was estimated cultivated area in 786 thousand of hectare with a production of 19.377 million tonnes. In Chhattisgarh, total production of tomato is 11 , $33,435 \mathrm{mt}$ from an area of about 64,681 ha (2017-18). In Chhattisgarh accounts for about $4.98 \%$ of the total production of tomato in the country. The productivity of tomato crop in Chhattisgarh is $16.42 \mathrm{mt} \mathrm{ha}^{-1}$. which is found lower to all India average of $21.99 \mathrm{mt} \mathrm{ha}^{-1}$. The major tomato producing districts are Raipur, Durg, Bastar, Balod and Jaspur. (Anonymous, 2017-18). Average productivity of tomato crop is quite low and there exists a good scope to improve its average productivity in Chhattisgarh as well as in India to fulfill both domestic and national needs. The growth, yield and fruit quality of tomato are largely dependent on number of interacting factors. On the other hand tomato is a long duration crop with high yield which removes large quantities of nutrients from the soil. Like macronutrients, micronutrients are equally significant in plant nutrition. There is a need to go for balanced fertilization of both macro and micronutrients since micronutrients play a profound role in various metabolic functions of plant. Zinc is an essential component of a number of enzymes i.e., dehydrogenase, aldolase, isomerise, proteinase, peptidase and phospho-hydrolase (Mousavi, 2011).

A field trial was carried out at the 10 farmer's field at Kanker district of Chhattisgarh comes in Agro-climatic zone of Bastar platue zone. Here, generally in winter's minimum 
temperature goes to $14-15^{\circ} \mathrm{C}$ and in summer maximum temperature reaches to $42{ }^{\circ} \mathrm{C}$, annual rainfall is $1200-1400 \mathrm{~mm}$ per year. There is lot of scope of tomato growing in this area. Dissemination of the technologies FLD is playing a very important role for transfer of technologies and changing scientific treatment of the farmers by seeing and believing principle. In order to have better impact of the demonstrated technologies for farmers and field level extension functionaries, front line demonstrations was conducted at farmer's field, in a systemic manner, to show case the high yielding new varieties, to convince them to about the potential of improved production technologies to enhance yield of tomato. Generally, the agricultural technology is not accepted by the farmers as such in all respects. There is always gap between the recommended technology by the scientist and its modified form at the farmer's level which is major absentee in the efforts of increasing agricultural production in the country. It is need of the hour to reduce this technological gap between the agricultural technology recommended by the scientists or researchers and its acceptance by the farmers on their field. In view of the above facts, front-line demonstrations were undertaken in a systematic manner on farmer's field to show the worth of improved practices and convince the farmers to adopt in their farming system.

\section{Materials and Methods}

The present study was conducted in Kanker district of Chhattisgarh during rabi 2016-17. Technology that is use cultivar Arka rakshak is a high yielding F1 hybrid with triple disease resistance to tomato leaf curl virus, bacterial wilt and early blight. Fruits square round, medium large (80-90 g), deep red, firm and suitable for fresh market and better fruit quality attributes like uniform fruit weight, shape, colour and shelf life (18-20 days), gives $25-30 \%$ higher yield $\left(75-80\right.$ ton $\left.\mathrm{ha}^{-1}\right)$ in 140 days. Improved yield with reduction in use of pesticides and fungicides due to its triple resistance to important diseases. The genuine seeds of tomato cultivar Arka rakshak were procured and distributed to ten selected farmers. All the participating farmers were trained on various aspects of tomato production technologies. The field was prepared by deep ploughing and harrowing. The seeds were sown in well prepared raised bed during first week of October. All the recommended practices i.e. seed treatment by carbandazim $50 \%$ W.P. @ $3 \mathrm{~g} \mathrm{~kg}^{-1}$ seed, transplanting of one month old seedlings, maintain in grow spacing of $90 \mathrm{~cm}$ and $60 \mathrm{~cm}$ spacing with in rows. Recommended dose of manure and fertilizers (10 tonnes FYM, N:P:K 60:100:75 $\mathrm{kg} \mathrm{ha}^{-1}$. respectively) as basal application before transplanting and remaining $90 \mathrm{~kg}$ nitrogen by three split doses 30, 45 and 60 days after transplanting. Weed management, need based plant protection chemicals were used to manage the problem. The zinc sulphate, boric acid and ferrous sulphate @ $50 \mathrm{mg}$. each per liter of water at 45 and 75 days after transplanting were sprayed additionally over farmers practice (control).The yield and economic performance of front line demonstrations, the data on output were collected from FLDs as well as local plots from all selected farmers and finally the grain yield, cost of cultivation, net returns with the benefit cost ratio was worked out. An average of cost of cultivation, yield and net returns of different farmers was analyzed by the formula.

Average $=\left[F_{1}+F_{2}+F_{3} \ldots \ldots \ldots . . . F_{n}\right] / N$

$\mathrm{F}_{1}=$ Farmer

$\mathrm{N}=$ No. of Farmers

In the present study, technology index was operationally defined as the technical feasibility obtained due to implementation of 
front line demonstrations in tomato. To estimate the technology gap, extension gap and technology index following formula used by Sagar and Chandra (2004) have been used.

Technology Gap

$=\mathrm{Pi}$ (Potential yield) $-\mathrm{Di}$ (Demonstration yield)

Extension Gap

$=\mathrm{Di}$ (Demonstration yield) $-\mathrm{Fi}$ (Farmers yield)

Technology Index

$=[($ Potential yield - Demonstration yield / potential yield) $\mathrm{X} 100$ ]

$\mathrm{B}: \mathrm{C}$ ratio

$=$ Net income $\left(\mathrm{Rs} \mathrm{ha}^{-1}\right) /$ Cost of cultivation (Rs ha ${ }^{-1}$ )

$\%$ Increased over farmers practices

$=($ Improved practices - Farmers practices $) /$ Farmers practices x100

\section{Results and Discussion}

\section{Performance of FLD}

A comparison of productivity levels between demonstration and farmers practice is shown in table 1. It is evident from results that under the demonstrated plots, performance of tomato (yield) was sustainable higher than in the local check. During the period of study, it was recorded that front line demonstrations tomato Hybrid variety Arka rakshak recorded the higher yield (471 $\left.\mathrm{q} \mathrm{ha}^{-1}\right)$ than farmers practice $\left(376 \mathrm{q} \mathrm{ha}^{-1}\right)$. The percentage increase in the yield (25.26) over farmers practice was recorded. Similarly, yield enhancement indifferent crops in front line demonstrations were documented by Mishra et al., (2018) and Dhaka et al., (2015). From these results it is evident that the performance of the technology demonstrated was found to be better than the farmers practice under same environment conditions. The farmers were motivated by seeing the results in term of productivity and they are adopting the technologies.

The yield of the front line demonstrations and potential yield of the crop was compared to estimate the yield gaps which were further categorized into technology index and technology gap. The technology gap shows the difference between potential yields over demonstration yield of the technology. The potential yield of the variety is $750 \mathrm{q} \mathrm{ha}^{-1}$. The technology gap $279 \mathrm{q} \mathrm{ha}^{-1}$ was recorded (Table $3)$. The front line demonstration was laid down under the supervision of Krishi Vigyan Kendra specialists at the farmer's field; there exist a gap between the potential yield and demonstration yield. This may be attributed to dissimilarities in soil fertility, salinity and to erratic rainfall and other vagaries of weather in the demonstration area. Hence, location specific recommendations may become necessary to narrow down the gap. These findings are similar to Sharma and Sharma (2004).

\section{Economics of frontline demonstrations}

Economics of tomato production under front line demonstrations was recorded and the results of the study have been presented in table 2. The results of economic analysis of tomato production revealed that front line demonstration recorded higher gross return (235500 Rs ha ${ }^{-1}$ ) and net return (Rs 155950) with higher benefit cost ratio (1:3.27) as compared to farmers practice. These results are in accordance with findings of Mishra et al., (2019) and Dhaka et al., (2015) further, additional cost of Rs $11500 \mathrm{ha}^{-1}$. In demonstration has increased additional net return Rs 35950 ha $^{-1}$. With incremental benefit cost ratio 1:3.11 suggesting it's higher profitability and economic viability of the demonstration (Table 3). 
Table.1 Level of use and gap in adoption extent of tomato technologies in study area

\begin{tabular}{|c|c|c|c|c|}
\hline S.No & $\begin{array}{l}\text { Package of practices } \\
\text { (Technology } \\
\text { intervention) }\end{array}$ & $\begin{array}{l}\text { Frontline demonstration } \\
\text { (Recommended practices) }\end{array}$ & $\begin{array}{l}\text { Farmers } \\
\text { (Local/check) }\end{array}$ & Gap \\
\hline 1 & Selection of variety & $\begin{array}{l}\text { Arka rakshak - Triple disease resistant } \\
\text { hybrid variety, resistance to leaf curling, } \\
\text { bacterial wilt and blight disease }\end{array}$ & Local variety & Partial gap \\
\hline 2 & Soil testing & Have been done all location & Not in practice & Full gap \\
\hline 3 & Seed rate & $100 \mathrm{gm} \mathrm{ha}^{-1}$ & $250 \mathrm{gm} \mathrm{ha}^{-1}$ & Partial gap \\
\hline 4 & Seed priming & $\begin{array}{l}\text { Seed priming was performed for better } \\
\text { germination. Seeds were soaked during } \\
\text { night for } 8-10 \text { hours with natural water, } \\
\text { drained out excess water and dried in } \\
\text { shade before sowing. }\end{array}$ & Not in practice & Full gap \\
\hline 5 & Seed treatment & Seed treated with fungicide Carbendazim & Seed treatment is not common & Full gap \\
\hline 6 & Spacing & $60 \mathrm{~cm} \times 20 \mathrm{~cm}$ & $120 \mathrm{~cm} \times 45 \mathrm{~cm}$ & Partial gap \\
\hline 7 & Growing trap crop & $\begin{array}{l}\text { Transplanting } 16: 1 \text { ratio of tomato and } \\
\text { marigold }\end{array}$ & Not grown any trap crops & Full gap \\
\hline 8 & $\begin{array}{ll}\text { Application } & \text { of } \\
\text { recommended dose } & \text { of } \\
\text { fertilizer } & \end{array}$ & $\begin{array}{l}150 \mathrm{~kg} \mathrm{~N}+100 \mathrm{~kg} \mathrm{P}_{2} \mathrm{O}_{5}+80 \mathrm{~kg} \mathrm{~K} \mathrm{~K}_{2} \mathrm{O} \text { per } \\
\text { ha }(50 \% \mathrm{~N}+100 \% \mathrm{PK} \text { at the time of } \\
\text { transplanting and remaining } 50 \% \mathrm{~N} \\
\text { applied at } 4 \text { week after transplanting }\end{array}$ & Imbalance and inadequate & Partial gap \\
\hline 9 & Irrigation & $\begin{array}{l}\text { Drip or furrow method of irrigation at } \\
\text { once in a } 4-7 \text { days interval depend upon } \\
\text { soil condition }\end{array}$ & $\begin{array}{l}\text { Once/twice furrow irrigation in } \\
\text { a week }\end{array}$ & Partial gap \\
\hline 10 & Weed management & $\begin{array}{l}\text { Pre-emergence herbicide butachlor @ } 1.5 \\
\mathrm{~L} \mathrm{ha}{ }^{-1} \text {, followed by hand weeding depend } \\
\text { upon weed intensity }\end{array}$ & Weeding is not common & Partial gap \\
\hline 11 & Training of plants & $\begin{array}{l}\text { Stake the plants } 30 \text { days after planting } \\
\text { with } 1.2-1.5 \mathrm{~m} \text { tall stakes. Remove the } \\
\text { side branches upto } 30 \mathrm{~cm} \text { from ground } \\
\text { level. }\end{array}$ & $\begin{array}{l}\text { Training of plants is not } \\
\text { common }\end{array}$ & Partial gap \\
\hline 12 & $\begin{array}{l}\text { Plant protection } \\
\text { measures for control of } \\
\text { insect pest and diseases }\end{array}$ & $\begin{array}{l}\text { Need based application for control: } \\
\text { Whitefly, thrips and sucking pest-spraying } \\
\text { with diamethoate ( } 30 \mathrm{EC}) 1.7 \mathrm{ml} \mathrm{L} \mathrm{L}^{-1} \text {. of } \\
\text { water. Fruit borer: Spay NPV ( } 250 \\
\left.\mathrm{LE} \mathrm{ha}^{-1}\right) \text {. Control of leaf curling- spraying } \\
\text { with imidaclopride } 0.3 \mathrm{ml} \mathrm{L}^{-1} \text { of water for } \\
\text { vector control. } \\
\text { Early blight- Spraying of mancozeb } 2 \mathrm{~g} \\
\mathrm{~L}^{-1} \text { of water. Fussarium wilt- Drenching } \\
\text { with copper oxy-chloride (COC) } 3 \mathrm{~g} \mathrm{~L}^{-1} \text { of } \\
\text { water. }\end{array}$ & Plant protection is not common & Partial gap \\
\hline 13 & Harvesting & Manual & Manual & No gap \\
\hline
\end{tabular}


Table.2 Economics of tomato through front line demonstrations

\begin{tabular}{|c|c|c|c|c|c|}
\hline Variables & Yield q ha ${ }^{-1}$ & $\begin{array}{l}\text { Cost of cultivation } \\
\left(\text { Rs ha }^{-1}\right)\end{array}$ & $\begin{array}{l}\text { Gross return } \\
\left(\text { Rs ha }^{-1}\right)\end{array}$ & $\begin{array}{l}\text { Net return } \\
\left(\text { Rs ha }^{-1}\right)\end{array}$ & $\begin{array}{l}\text { Benefit: cost } \\
\text { ratio }\end{array}$ \\
\hline $\begin{array}{l}\text { Farmers } \\
\text { practice }\end{array}$ & 376 & 68000 & 188000 & 120000 & $1: 2.76$ \\
\hline \multirow{2}{*}{$\begin{array}{l}\text { Recommended } \\
\text { practice }\end{array}$} & 471 & 79550 & 235500 & 155950 & $1: 3.27$ \\
\hline & 95 & 11500 & 47500 & 35950 & 3.11* \\
\hline
\end{tabular}

*Incremental benefit: cost ratio.

Table.3 Yield, technology gap, extension gap and technology index through front line demonstrations

\begin{tabular}{|l|l|l|l|l|l|}
\hline Variables & $\begin{array}{l}\text { Yield } \\
\left(\mathbf{q} \mathbf{~ h a}^{-\mathbf{1}}\right)\end{array}$ & $\begin{array}{l}\text { Increase (\%) over } \\
\text { farmers practice }\end{array}$ & $\begin{array}{l}\text { Technology gap } \\
\left(\mathbf{q} \mathbf{~ h a}^{-\mathbf{1}}\right)\end{array}$ & $\begin{array}{l}\text { Extension gap } \\
\left(\mathbf{q} \mathbf{h a}^{-\mathbf{1}}\right)\end{array}$ & $\begin{array}{l}\text { Technology index } \\
(\mathbf{\%})\end{array}$ \\
\hline $\begin{array}{l}\text { Farmers } \\
\text { Practice }\end{array}$ & 376 & - & - & - & - \\
\hline $\begin{array}{l}\text { Recommended } \\
\text { practice }\end{array}$ & 471 & 25.26 & 279 & 95 & 37.2 \\
\hline
\end{tabular}

More and less similar results were also reported by Hiremath and Nagaraju (2009) and Dhaka et al., (2010). On the basis of above finding in present study, it is concluded that front line demonstrations of improved technology reduces technology gap to a considerable extent, thus leading to increased productivity of tomato in Kanker district of Chhattisgarh. This also improved linkages between farmers and scientists, and built confidence for adoption of the improved technology. Productivity enhancement under FLD's over farmers practices of tomato cultivation created a greater awareness, and motivated other farmers not growing tomato to adopt improved technologies in this crop i.e. tomato.

\section{References}

Anonymous, (2015). KVKs impact on Dissemination of Improved Practices and Technologies by Indian Council of Agricultural Research (ICAR) National Institute of Labour
Economics Research and Development (NILERD). Pp. 10.

Anonymous, (2017-18). Indian Horticulture Database 2017-18. National Horticulture Board, Ministry of Agriculture, Government of India. Pp. 4.

Dhaka, B.L., Poonia, M.K., Meena, B.S. and Bairwa, R.K. 2015. Yield and economic viability of coriander under front line demonstrations in Bundi district of Rajasthan. J. Hortl. Sci., 1092: 226-28.

Dhaliwal, M.S. 2014. Handbook of vegetables crops, Kalyani Publishers, Pp. 38-39.

Hiremath, S.M., Nagaraju, M.V. 2009. Evaluation of frontline demonstration on onion in Haveri district of Karnataka. Karnataka J. Agric. Sci.,22(5): 1092-1093.

Mishra, D.K., Paliwal, D.K., Tailor, R.S. and Deshwal, A.K. 2009. Impact of front line demonstrations on yield enhancement of potato. Indian Res. J. Ext. Edu., 9(3): 26-28. 
Mishra, K. and Debasis, S. 2018 Impact of front line demonstration on yield and economics of sweet corn variety (Madhuri). International J. of Curr. Microbiology and App Sci., 6(9): 1489-1497.

Mousavi, S.R. 2011. Zinc in crop production and interaction with phosphorus. Aust.J. Basic Appl. Sci., 5(9): 15031509.

Sagar, R.L. and Chandra, G. 2004. Evaluation of front line demonstrations on mustard in Sunderban, West Bengal. Indian J.Exten.Edu., 40: 96-97.

Sharma, R.N. and Sharma, K.C. 2004.
Evaluation of front line demonstration trials on oilseeds in Baran district of Rajasthan. Madhya J.Exten.Edu., 7: 72-75.

Suryawanshi, S.D. and Prakash, M. 1993. Impact of viable technology of promoting oil seeds in Maharastra. Indian J. Agri.Econ.,48(420): 102-106.

Thakur A. and Yadav S. 2017 Impact of front line demonstration (FLD) on the Yield and economics of small millet on Bastar district of Chhattisgarh, India. International J. of Curr. Microbiology and App. Sci. 6:1489-1497.

\section{How to cite this article:}

Suresh Kumar Markam, Birbal Sahu, Komal Singh Keram and Chandu Lal Thakur. 2019. Yield and Economic Viability of Tomato (Solanum lycopersicum Mill) under Front Line Demonstrations in Kanker District, Chhattisgarh, India. Int.J.Curr.Microbiol.App.Sci. 8(12): 1393-1399. doi: https://doi.org/10.20546/ijcmas.2019.812.168 